\title{
The effect of macrofauna, meiofauna and microfauna on the degradation of Spartina maritima detritus from a salt marsh area
}

\author{
Ana Isabel Lillebø ${ }^{\mathrm{a} *}$, Mogens R. Flindt ${ }^{\mathrm{b}}$, Miguel Ângelo Pardal ${ }^{\mathrm{a}}$, João Carlos Marques a \\ ${ }^{a}$ IMAR - Institute of Marine Research, Department of Zoology, University of Coimbra, 3004-517 Coimbra, Portugal. \\ ${ }^{b}$ Freshwater Biological Laboratory, University of Copenhagen, Helsingørsgade 51, Dk-3400 Hillerød, Denmark. \\ * Corresponding author (fax: +35139 823603; e-mail: ailimar@gemini.ci.uc.pt)
}

Received February 26, 1998; revised December 30, 1998; accepted February 26, 1999

\begin{abstract}
Decomposition of salt marsh plants results from physical, chemical and biological processes including abiotic and biotic fragmentation, microbial decay and chemical transformation. According to literature data, only a few species have the ability to feed directly on living plant material, so fungi and bacteria seem to be the principal competitors for the organic substrates. Nevertheless, by consuming bacteria, protists and fungi associated to the detritus, macrofauna and meiofauna recycle the incorporated nutrients. Moreover, this nutrient regeneration may be seen as an effective factor in maintaining and stimulating bacterial production. In fact, it is well known that many detritus feeding species have very low assimilation efficiencies. The objective of the present study was to compare the nutrient mass balance of carbon; nitrogen and phosphorus in Spartina maritima covered areas and bare bottom sediment, with and without contribution of macrofauna, meiofauna and microbial populations. Nutrients mass balance was studied taking into account the initial and final nutrient concentrations in the sediment, water and plant material. Faunal activity was measured as a function of remineralised carbon, nitrogen and phosphorus. The experimental set-up included sixteen sub-experiments, which varied with respect to type of fauna, plant biomass and oxic status. Each sub-experiment was performed in small glass containers $(3 \mathrm{~L}$ ) containing about $900 \mathrm{~g}$ wwt sediment and $2.5 \mathrm{~L}$ estuarine water. Plant material, cut from intact plants, sediment cores and estuarine water were brought from the southern arm of the Mondego estuary (Portugal). The results showed that although the bacterial activity was responsible for the Spartina maritima degradation, the presence of meiofauna and macrofauna significantly enhanced the process. Moreover, the presence of Spartina maritima positively affected the mineralisation of the sediment carbon and nitrogen, especially when the three faunal components were present, and denitrification rates were highest in the presence of the macrofauna and meiofauna. The present study suggests that macrofauna and meiofauna have an important role on the ecosystem nutrient flux and that fauna might function as a sink for excess nutrients, that otherwise could be exported to the coastal waters. () 1999 Éditions scientifiques et médicales Elsevier SAS
\end{abstract}

Spartina maritima / decomposition / fauna / nutrient mass balance

\section{INTRODUCTION}

Salt marshes are often considered as very productive aquatic ecosystems, where rooted macrophytes such as Spartina sp. are able to reach high biomass during the growing season $[4,5,19,20,21]$.

Several studies on aquatic and terrestrial plants have shown that the decay of plant detritus depends on the availability of the plant nutrients $[5,6,7,12,21]$. The amount of structural parts, such as lignin and cellulose, and the nutritional $\mathrm{C}: \mathrm{N}: \mathrm{P}$ ratio of the plant, affect the overall mineralisation rates [5]. Several authors have shown that only a small fraction of the plant production is consumed by herbivores [5, 20]; instead the leaves are sloughed with ageing, or the tide motion mechanically fractionates them. So, most of the Spartina production enters the detritus pathway and remain within the marsh area, or is exported to the coastal waters $[7,18,19]$. As a result of the nutrient balance and the amount of structural tissue, Spartina has a relatively low mineralisation rate.

Degradation includes several different temporal phases [9] that can be resumed in three steps: 1) initial leaching of easy degradable low molecular cellular substances; 2) decomposition of the structural parts; and 3) slow degradation of the more structural plant material. In the initial stages of decomposition, the impact of the macrofauna and meiofauna seems to be negligible, but the effect increases with time [21]. Although, organic matter is primarily degraded by 
Table I. Spartina maritima laboratory experiment set-up. Plant biomass is expressed in g of wet weight.

\begin{tabular}{lcccccc}
\hline Items & Leaves & Roots & Oxic State & Macrofauna & Meiofauna & Bacteria \\
\hline Bare sediment & 0.000 & 0.000 & + & + & + & + \\
Bare sediment & 0.000 & 0.000 & + & + & + & + \\
Bare sediment & 0.000 & 0.000 & - & - & - & + \\
Bare sediment & 0.000 & 0.000 & - & + & + & + \\
Spartina maritima & 2.012 & 0.507 & + & + & + & + \\
Spartina maritima & 4.021 & 1.003 & + & + & + & + \\
Spartina maritima & 8.031 & 2.069 & + & + & + & + \\
Spartina maritima & 2.028 & 0.510 & + & - & + & + \\
Spartina maritima & 4.011 & 1.059 & + & - & - & + \\
Spartina maritima & 8.017 & 2.014 & + & - & - & + \\
Spartina maritima & 2.030 & 0.506 & + & - & - & + \\
Spartina maritima & 4.029 & 1.033 & + & - & + \\
Spartina maritima & 8.017 & 2.071 & + & - & + \\
Spartina maritima & 2.030 & 0.510 & - & - & + \\
Spartina maritima & 4.013 & 1.003 & - & - & + \\
Spartina maritima & 8.006 & 2.081 & - & - & + \\
\hline
\end{tabular}

micro-organisms, their presence also enhances the nutritional quality of leaf litter for the macro invertebrate [10]. This was verified after temporal measurements showing that litter had a lower $\mathrm{C}: \mathrm{N}$ ratio due to heterotrophic bacteria colonisation [16].

It is known that benthic fauna can feed on detritus formed by bacterial decomposition of Spartina and macroalgae [4, 19, 20, 21], but not much is known about the role of different fauna levels on Spartina maritima detritus degradation, or to what extent the macrofauna and meiofauna affect the nutrient dynamics during the decay process. Therefore, this study focuses on the nutrient mass balance during $S$. maritima decomposition, and the role of the macrofauna and meiofauna compared with an oxic and anoxic microbial degradation of Spartina detritus.

\section{MATERIALS AND METHODS}

Sediment, water, Spartina maritima and macrofauna were collected in the southern arm of the Mondego estuary (Portugal) (see also $[2,15]$ ). The laboratory set-up made it possible to measure the aerobic and anaerobic degradation of plant material and sediment organic matter, simulating in situ high tide conditions. The experimental set-up included sixteen subexperiments, that were performed in small glass containers of $3 \mathrm{~L}(\varnothing: 14.0 \mathrm{~cm})$, each containing about $900 \mathrm{~g}$ (wwt) of sediment, composed namely by silt and clay, and $2.5 \mathrm{~L} \mathrm{GF/F}$ filtered estuarine water $(20 \%$ ).
The sediment was previously sieved (1-mm mesh size) and mixed to improve the homogeneity among containers.

All plant material was gently washed with estuarine water and weighed ( $g$ wwt) before being placed in containers. Different plant biomass, as outlined in table I, were chosen to represent realistic values for the salt marsh area of the Mondego estuary. Spartina maritima leaves were still green, when cut from intact plants, and placed vertically on the sediment surface, while roots were buried at $3-\mathrm{cm}$ depth. Macrofauna was carefully sorted from the sediment and each individual used in the experiment was previously measured $(\mathrm{mm})$ or weighed $(\mathrm{g} w \mathrm{wt})$. Previous studies on macrofauna population dynamics in the Mondego estuary provided the regression models to calculate the initial biomass values in AFDW (ash free dry weight) $[13,14,17]$.

The effect of the bacterial degradation was measured by isolating their activity, from the faunal activity, by adding the eukariotic toxin cyclohexamide into the relevant containers. In other containers, macrofauna representing real field abundance was added to the sieved sediment (table II), while meiofauna and bacteria only affected the plant degradation in other. Bubbling with atmospheric air ensured oxic conditions, while the anoxic conditions were formed during the first day of the experiment, due to the oxygen consumption in the closed containers. 
Table II. Macrofauna species composition and total initial biomass (g AFDW).

\begin{tabular}{lcc}
\hline Species composition & Items & $\begin{array}{c}\text { Macrofauna } \\
\text { (g AFDW) }\end{array}$ \\
\hline Scrobicularia plana & Bare sediment & 0.2825 \\
Nereis diversicolor & Bare sediment & 0.2822 \\
Hydrobia ulvae & Spartina maritima (2 g AFDW) & 0.2636 \\
Cyathura carinata & Spartina maritima (4 g AFDW) & 0.2753 \\
Oligochaeta sp. & Spartina maritima (8 g AFDW) & 0.2821 \\
\hline
\end{tabular}

All containers were incubated in darkness at $20^{\circ} \mathrm{C}$, to avoid primary production. Samples were taken for nutrient analysis of plant, water and sediment, corresponding to the initial and final conditions of the experiment. Plant material (leaves and roots) subsamples were used to analyse plant dry weight, loss on ignition $\left(3 \mathrm{~h}, 450{ }^{\circ} \mathrm{C}\right)$ and $\mathrm{C}, \mathrm{N}$ and $\mathrm{P}$ content. All water samples were filtered $(\mathrm{GF} / \mathrm{F})$ and kept frozen until analysis. The removed water was replaced with filtered estuarine water with known concentrations of nutrients. In the budget, this removal of nutrients and dilution were taken into account. Sediment triplicate sub-samples were analysed for dry weight, loss on ignition $\left(8 \mathrm{~h}, 450{ }^{\circ} \mathrm{C}\right)$, total nitrogen and phosphorus.

At the end of the experiment, Spartina leaves and roots were easily identified and separated from the sediment and analysed for total C, N, P and loss on ignition. Sediment sub-samples from each container were removed, homogenised and analysed for total N, $\mathrm{P}$ and loss on ignition. Macrofauna was carefully sorted from the sediment (1-mm mesh sieve) and the biomass quantified (g AFDW).

\subsection{Analytical procedure}

Analyses for dissolved reactive phosphate, ammonia and nitrate were measured on a rapid flow autoanalyser (RFA 300 Alpkem) and performed according to Alpkem methodologies [1]. Before elementary analyses, all plant material was dried to constant weight at $105^{\circ} \mathrm{C}$, and analysed for carbon and nitrogen content (CHN-analyser, Carlo Erba), while total phosphorus was measured according to standard methods. Organic carbon in the sediment was estimated as $40 \%$ mass of the loss on ignition $\left(8 \mathrm{~h}, 450{ }^{\circ} \mathrm{C}\right)$. Denitrification was calculated considering the difference between the initial and the final amounts of nitrogen in the oxic systems, assuming a steady state in the bacterial biomass, during the experiments [6].

\subsection{Data analysis}

Statistical treatment (one-way ANOVA: $95 \%$ Tukey's HSD intervals method) was performed with
MINITAB 10.1 software package. All data were previously transformed as arcsine $(\sqrt{\text { value }})$, according to Zar [23].

\section{RESULTS}

In the present study, abiotic processes were assumed irrelevant. Available information from a similar set-up, concerning Zostera marina and Ulva sp. degradation, showed that mineralisation of plant material was purely biotic [6].

During the study period of $99 \mathrm{~d}$, the degradation of S. maritima leaves was significantly different (Tukey's test; one-way ANOVA, $n=3, P=0.001$ ) when the three fauna levels were present, corresponding to $92 \%$ of the initial biomass. With the decrease in faunal complexity, there were no significant differences among the fauna levels, which corresponded to $74 \%$ when meiofauna and bacteria were present and $67 \%$ when just bacteria were present (figure 1A). During degradation of roots, $67 \%$ of the root biomass were degraded in the presence of bacteria, when both meiofauna and bacteria were present, the degradation rose up to $77 \%$ (figure $1 B$ ). For the same experiment, the role of macrofauna was not so conclusive and there were no significant differences among the experiments. Results concerning S. maritima degradation under anoxic conditions were very similar to the oxic conditions in the presence of bacteria, and bacteria and meiofauna.

In the $S$. maritima decomposition process, the mineralisation followed the order $\mathrm{C}<\mathrm{N}<\mathrm{P}$. Although there was always carbon conservation, carbon mineralisation increased with the increase of fauna complexity. Considering the three elements $(\mathrm{C}, \mathrm{N}, \mathrm{P})$, the highest mineralisation rates of leaves occurred when macrofauna, meiofauna and bacteria were present: $93 \% \mathrm{C}, 96 \% \mathrm{~N}$ and $97 \% \mathrm{P}$ (figure $2 A$ ). In fact, the presence of the three fauna levels was significantly different from the other containers in respect to mineralised carbon (Tukey's test; one-way ANOVA, $n=3 ; P=0.001$ ), and nitrogen (Tukey's test; one-way ANOVA, $n=3 ; P=0.001)$. But the mineralised phosphorus was just significantly different from anoxic conditions (Tukey's test; one-way ANOVA, $n=3$, $P=0.022$ ). The other fauna levels were not statistically different from each other. At the end of the experiment, $61 \%$ of the initial $\mathrm{C}$ content of leaves were already mineralised in the presence of bacteria, $72 \%$ when both meiofauna and bacteria were present, and $92 \%$ when the three fauna levels were present (figure 2A). These relationships were not so clear 
A

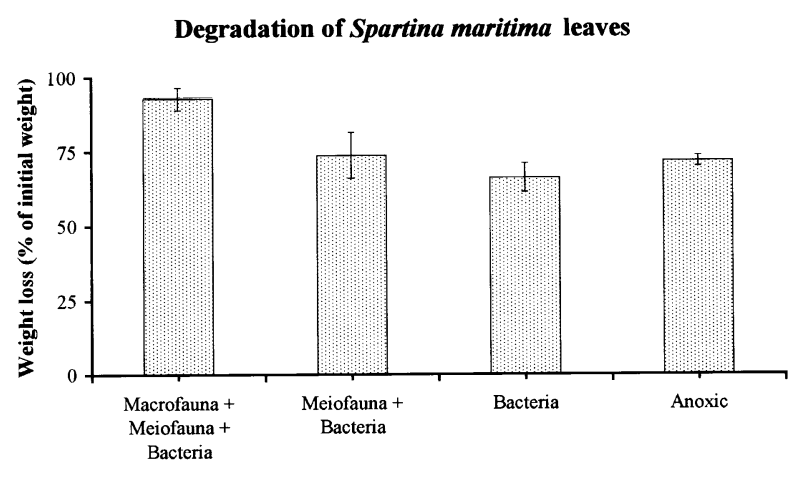

B

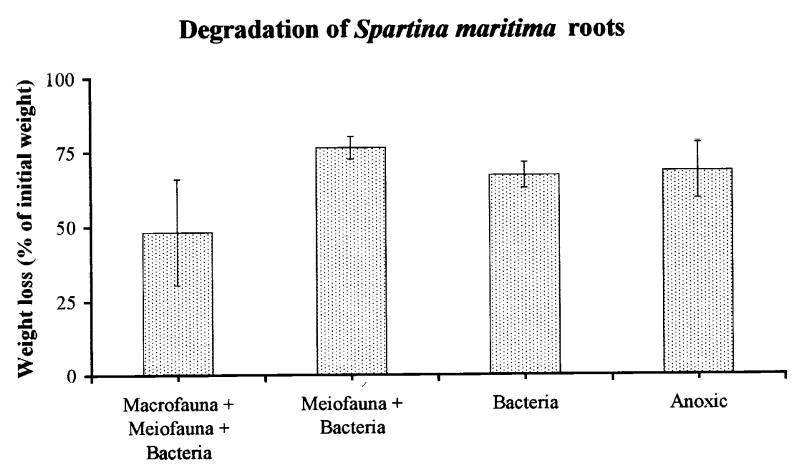

Figure 1. Weight loss of Spartina maritima, during $99 \mathrm{~d}$ of degradation, in the presence of just bacteria, under anoxic and oxic conditions; bacteria and meiofauna, and bacteria, meiofauna and macrofauna (mean \pm standard deviation, $n=3$ ). A: Leaves; B: roots.

during the mineralisation of root and there were no significant differences among the fauna levels. Nevertheless, mineralisation rates were slightly higher in the presence of meiofauna and bacteria (figure $2 B$ ). The initial $\mathrm{C} / \mathrm{N}, \mathrm{C} / \mathrm{P}$ and N/P values, for leaves and roots, are shown in table III.

Regarding the mineralisation of POM in the sediment pools, the addition and degradation of Spartina maritima enhanced the mineralisation of carbon, nitrogen and phosphorus, when compared to the bare

Table III. Spartina maritima initial $\mathrm{C} / \mathrm{N}, \mathrm{C} / \mathrm{P}$ and N/P value in leaves and roots.

\begin{tabular}{lccc}
\hline Spartina maritima & $\mathrm{C} / \mathrm{N}$ & $\mathrm{C} / \mathrm{P}$ & $\mathrm{N} / \mathrm{P}$ \\
\hline Leaves & 16.22 & 94.92 & 5.85 \\
Roots & 24.54 & 78.58 & 3.24 \\
\hline
\end{tabular}
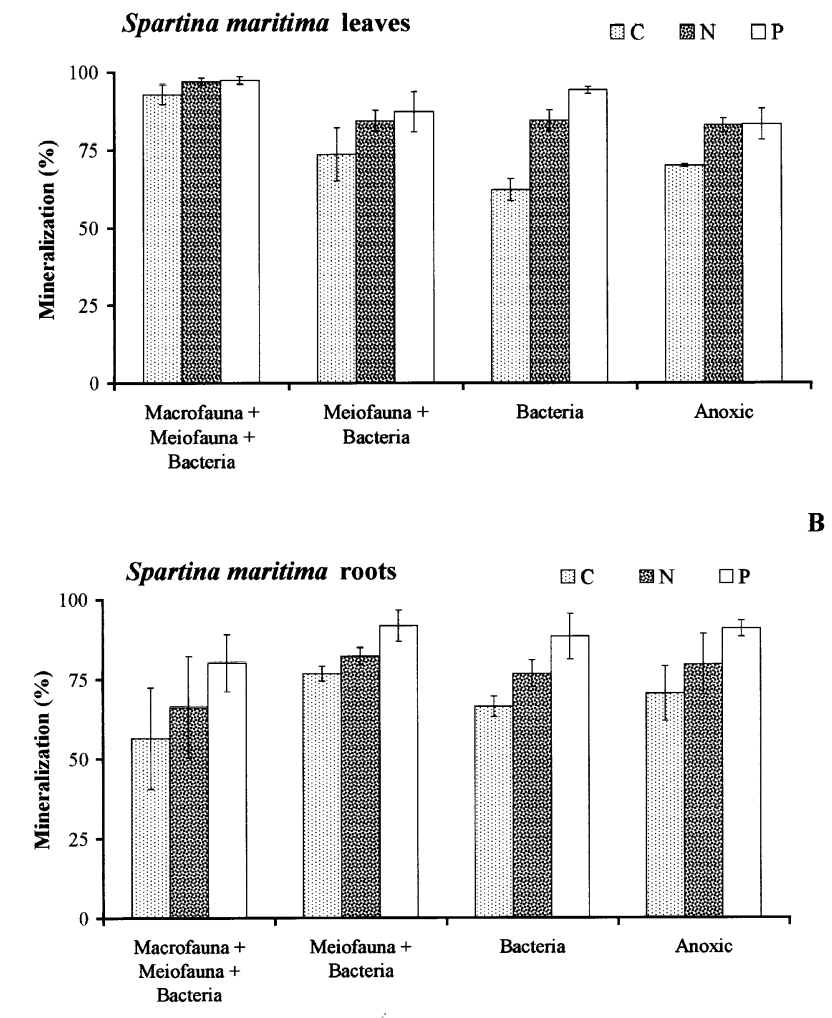

Figure 2. Comparison of the initial percentage of Spartina maritima mineralisation, during $99 \mathrm{~d}$, in the presence of bacteria only under anoxic and oxic conditions, bacteria and meiofauna, and bacteria, meiofauna and macrofauna (mean \pm standard deviation, $n=3$ ). A: Leaves; B: roots.

bottom containers (figure 3). Mineralisation was also higher in the containers with $S$. maritima under oxic conditions. The highest mineralisation occurred when plant material and macrofauna, meiofauna and bacteria were present. Nitrogen mineralisation increased from anoxic to oxic conditions and with the increase of fauna complexity.

Considering mineralisation on a mass balance scale, very different amounts of mineralised dissolved nutrients appear in the water column during the experiment. Under oxic conditions, organic carbon and nitrogen concentrations were lower at the end of the experiment (figure $4 A, B$ ), while phosphorus to some extent was reformed as phosphate in the water-phase (figure $4 C$ ). Regarding nitrogen mass balance in the water-phase, results show that in the anoxic experiments, all mineralised sediment particulate organic nitrogen and plant component nitrogen were re-found as an increase 


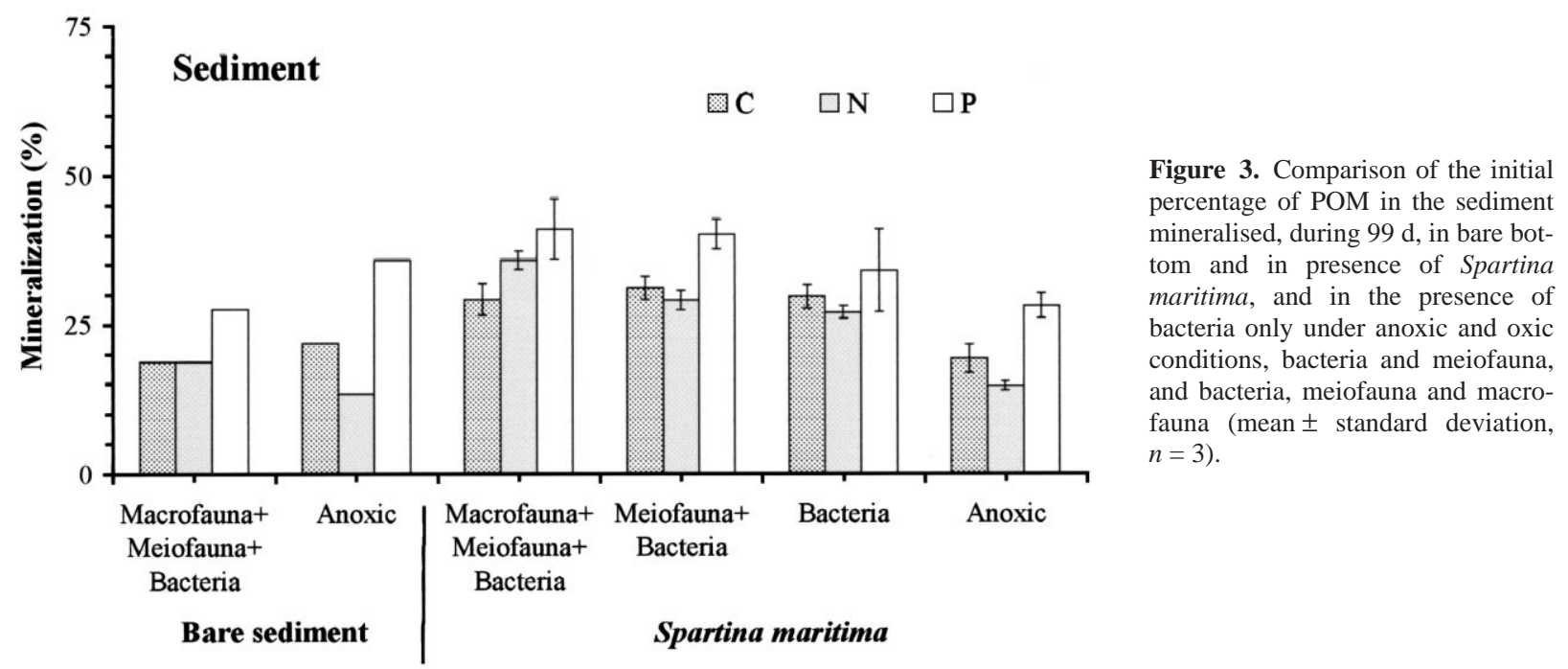

in the ammonia pool (figure 5A); while in the oxic experiments, there was an increase in the nitrate pool (figure $5 B$ ). The highest nitrate concentrations were found in the containers with bacteria, meiofauna and macrofauna. At the end of the experiment and regarding phosphorus mass balance in the water-phase, concentrations in the water column clearly increased (figure 5C).

The highest nitrification processes occurred when macrofauna, meiofauna and bacteria were present (figure $5 B$ ). This increase in nitrate production may allow denitrification to take place. In fact, denitrification rates were much higher under aerobic conditions and in the presence of the three fauna levels (figure 6). Considering the relative denitrification rates, it is clear that it was higher in the experiments with S. maritima, and that it increases with the increase of fauna complexity (figure 7). In the anoxic experiment with plant material, the not-shown values corresponded to negative denitrification rates that will be discussed further.

\section{DISCUSSION}

For the same period of time (99 d), although microbial activity was responsible for at least $67 \%$ of Spartina maritima degradation, the increase in fauna complexity increased the degradation process. In fact, macrofauna detritus feeding activity may change the microbial flora and stimulate the microbial activity [21]. In this experiment, macrofauna species, such as Hydrobia ulvae, might by their feeding activity on leaves' surfaces [3] contribute to the fragmentation of the plant material and stimulate the microbial activity. Moreover, meiofauna may also enhance the use of detritus by macrofauna [21]. The role of macrofauna in root degradation is not well defined, probably because most of the individuals belong to the epibenthic groups and roots were placed at $3 \mathrm{~cm}$ depth. Nevertheless, the presence of meiofauna enhanced the degradation of roots by $9 \%$. The higher bacterial degradation recorded under anoxic conditions (without cyclohexamide), may result from the presence of anaerobic flagellates, that could enhance the degradation processes by $5 \%$, when compared to the aerobic microbial degradation for the same period of time.

Although it seems that in the initial stages of decomposition the impact of meiofauna may be negligible, it tends to increase in the course of time [21]. In fact, the highest mineralisation rate of Spartina leaves occurred when macrofauna, meiofauna and bacteria were present, and in root material, mineralisation rates were slightly higher in the presence of meiofauna. It seems that meiofauna and macrofauna do not compete for bacteria as food resource since meiofauna species are able to support a bacterial production, by recycling nutrients and inducing their activity [4]. Furthermore, micro-organisms' activity may enrich the nutrient palatability and nutrient quality of leaf litter for macro-invertebrate consumption [10]. Other studies showed that polychaetes can incorporate significantly more carbon from detritus of Spartina and Zostera when meiofauna is present [21]. 


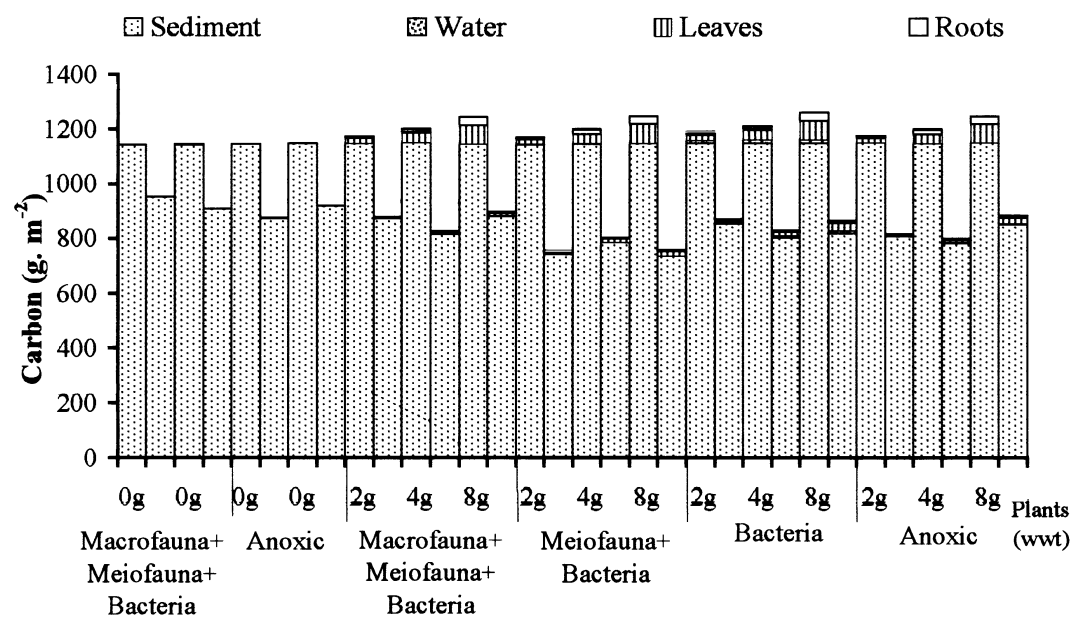

B

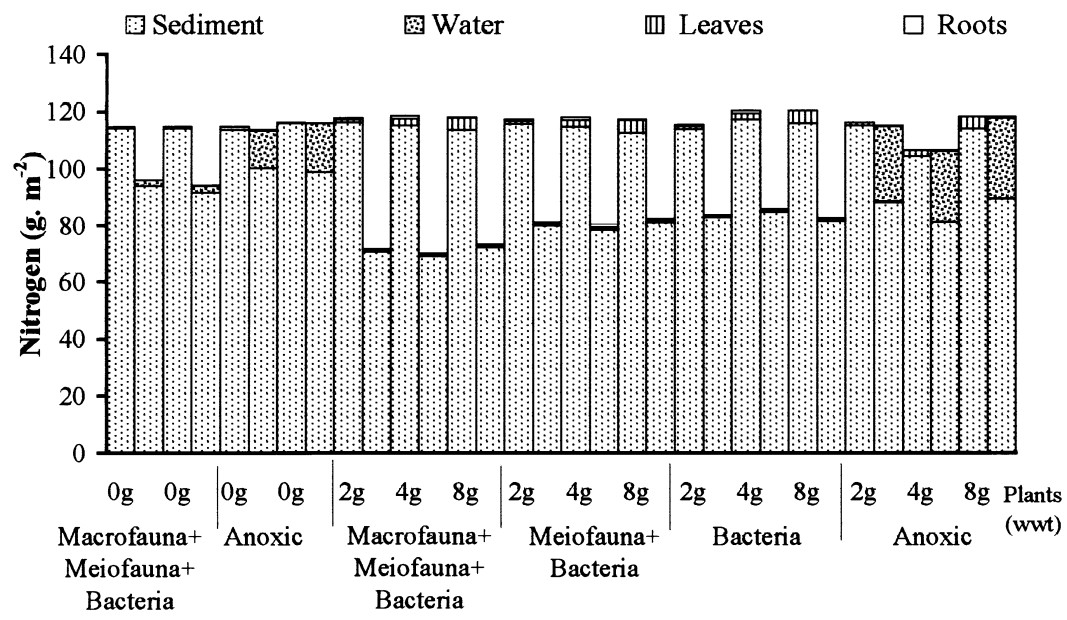

C

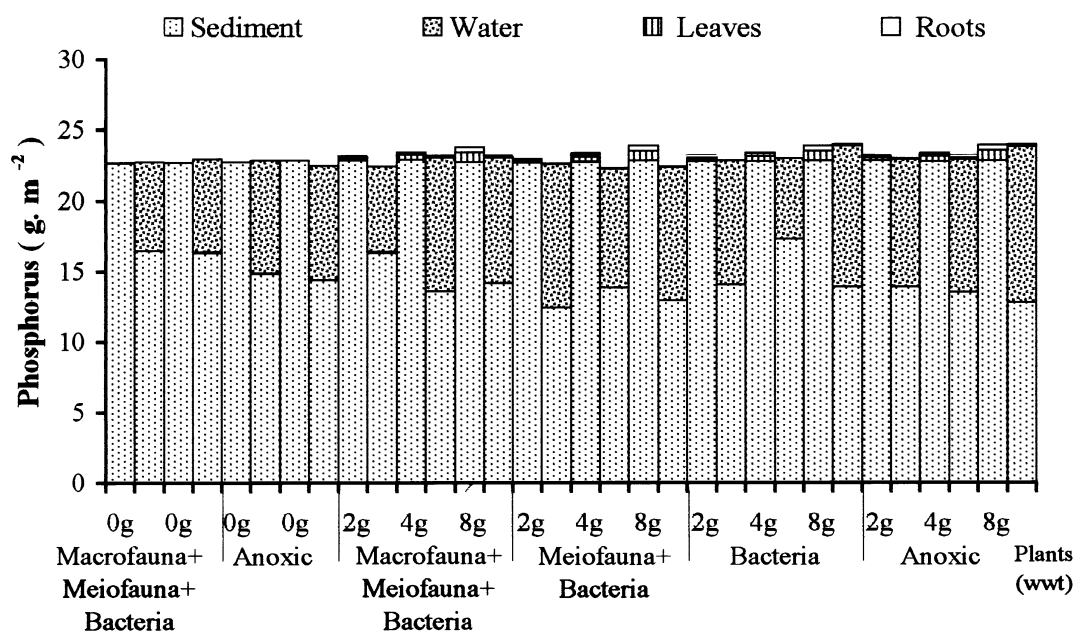

Figure 4. Mass balance of carbon, nitrogen and phosphorus in bare bottom and in presence of Sparina maritima, and in the presence of bacteria only under anoxic and oxic conditions, bacteria and meiofauna, and bacteria, meiofauna and macrofauna. The two bars per experiment represent the initial and final amounts of the element in the sediment, water column and plant material, respectively. A: Carbon; B: nitrogen; C: phosphorus. 


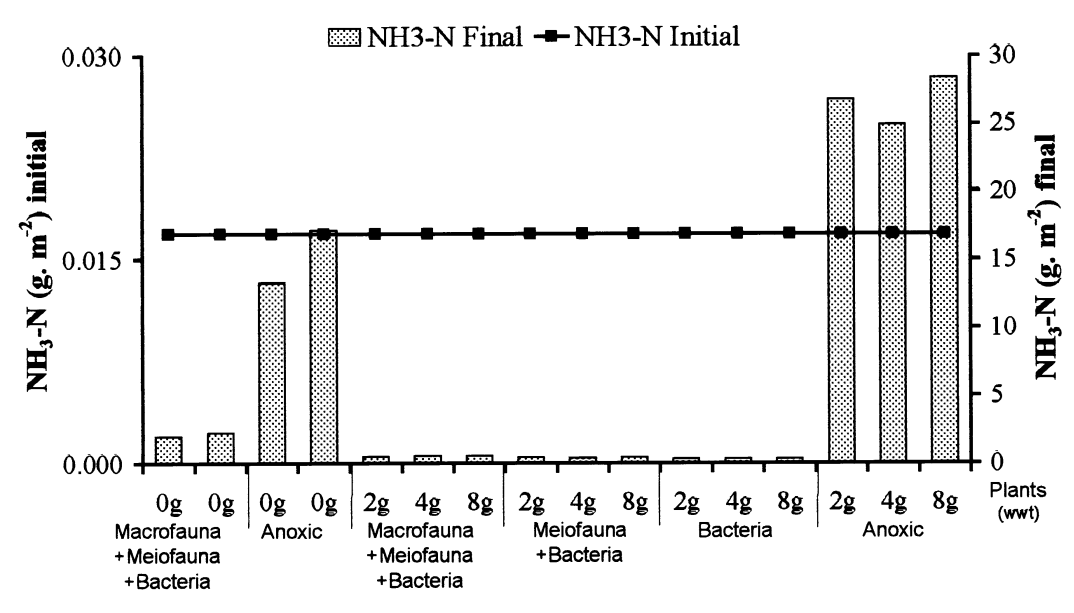

B

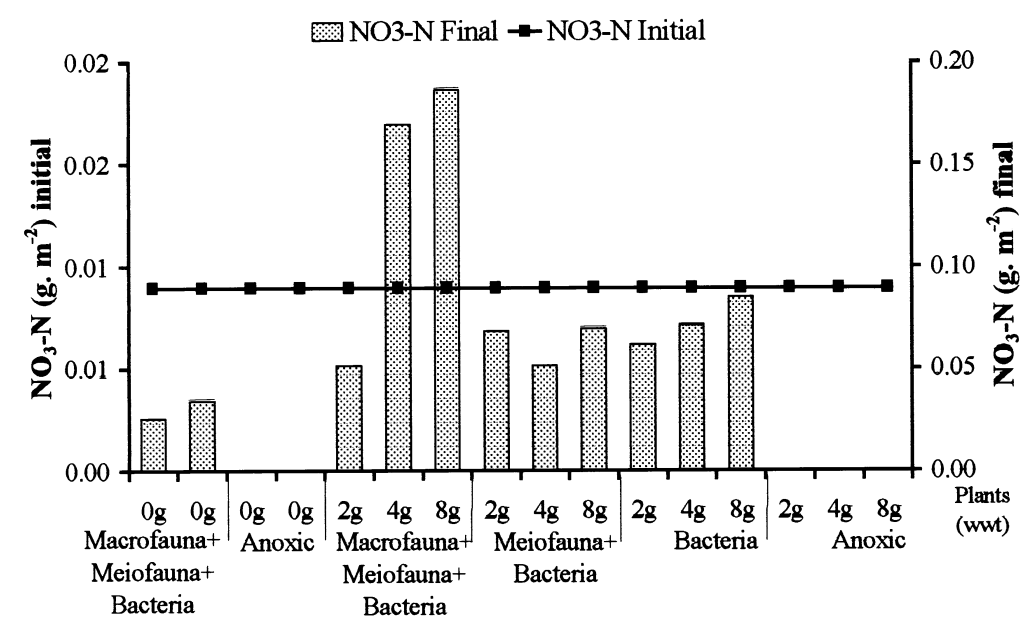

C

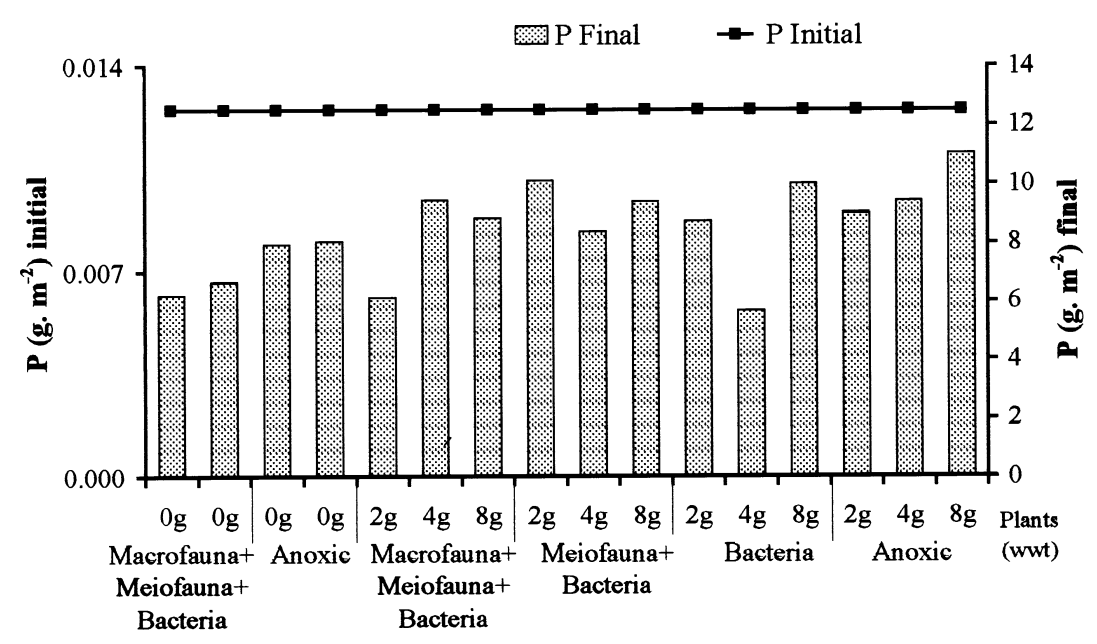

Figure 5. Nitrogen and phosphorus mass balance in the water-phase, in bare bottom and in presence of Spartina maritima, and in the presence of just bacteria under anoxic and oxic conditions, bacteria and meiofauna, and bacteria, meiofauna and macrofauna. The line and the bar per experiment represent, respectively, the initial and final amounts of the element. A: Ammonia; B: nitrate; C: phosphorus. 


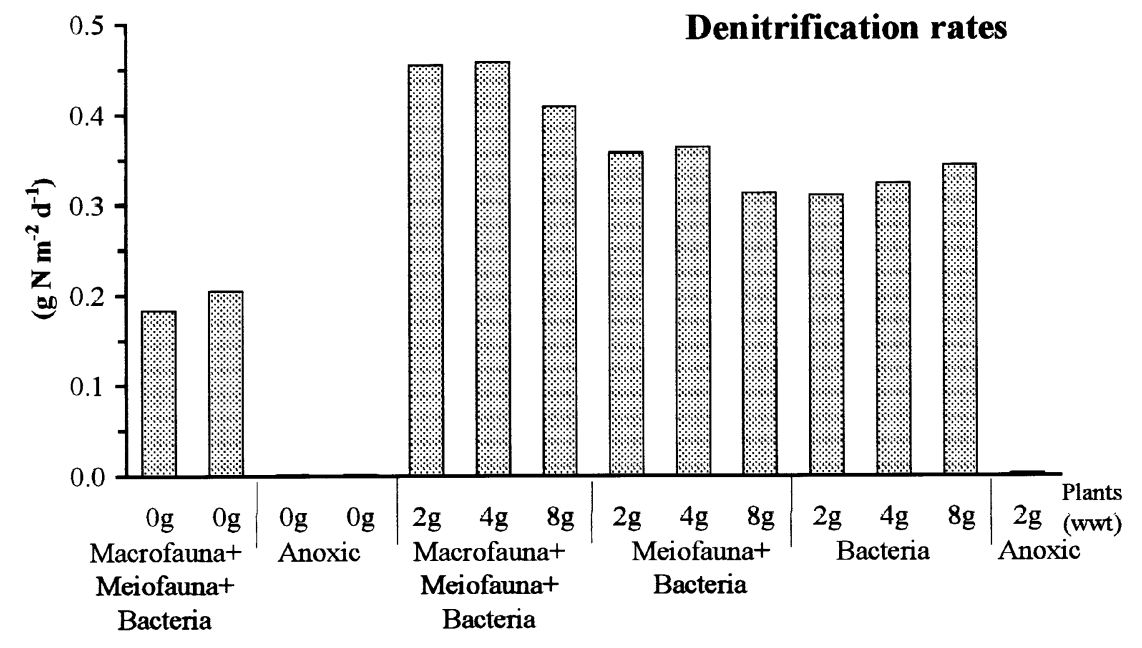

Figure 6. Denitrification rates during the experiments in bare bottom and in presence of Spartina maritima, and in the presence of bacteria only under anoxic and oxic conditions, bacteria and meiofauna, and bacteria, meiofauna and macrofauna.
Although, bacteria are the first catabolisers of organic matter [10], benthic macrofauna feeds on detritus formed by bacterial decomposition activity and both macrofauna and meiofauna may feed directly on bacteria [4].

The faster mineralisation of $\mathrm{N}$ and $\mathrm{P}$ can be related to the fact that the initial $\mathrm{C} / \mathrm{N}$ and $\mathrm{C} / \mathrm{P}$ ratio of the leachate were low [7]. This is a general tendency, because most of the phosphorus is present in the intracellular plant part as ATP, RNA and DNA, and most of the nitrogen is found in the protein pool. All these substances are among the easy leaching components when the plant dies. Although the percentage of

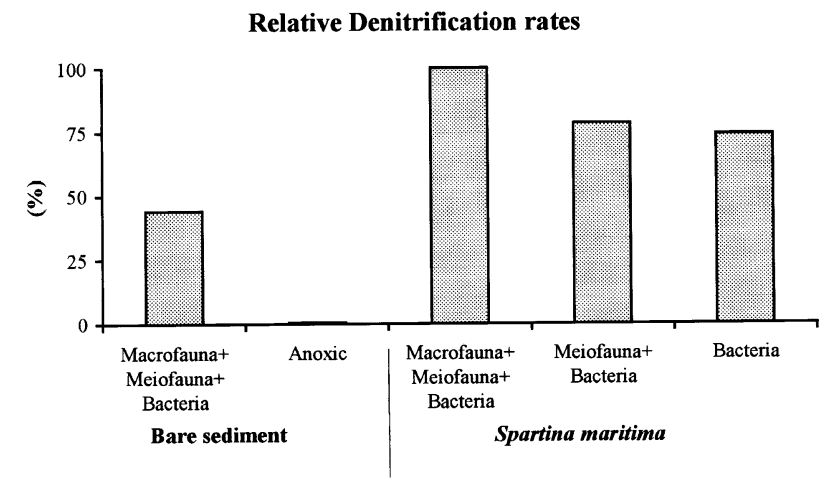

Figure 7. Relative denitrification rates during the experiments in bare bottom and in presence of Spartina maritima, and in the presence of bacteria only under anoxic and oxic conditions, bacteria and meiofauna, and bacteria, meiofauna and macrofauna.
S. maritima biomass remaining was much higher in a litter bag field study, the percentage of initial nitrogen and phosphorus mineralised, for the same period is comparable [19]. Several authors have considered that the degradability of plant material is directly proportional to the nitrogen content $[9,12]$, and mentioned that, during the early mineralisation of plant materials, more nitrogen than carbon is retained, through the action of aerobic micro-organisms [12].

It is well known that decomposition of particulate organic matter is faster under aerobic conditions. It was therefore an open question if the non-degraded plant material, instead of being mineralised, fertilised the sediment organic pool as detritus. As a net result, this did not happen either in the oxic or the anoxic experiment. Sediment organic pools were also mineralised during the experiment and the addition of $S$. maritima positively affected the mineralisation of sediment carbon and nitrogen, as well as the presence of macrofauna, meiofauna and bacteria. These results are consistent with results from other authors, although fauna was not considered [7].

Considering mineralisation on a mass balance scale, very different amounts of mineralised dissolved nutrients appear in the water column. At the end of the experiment, organic carbon and nitrogen presented lower concentrations in the water column, while phosphorus to some extent was reformed as phosphate in the water-phase. Considering Valiela [21], phosphate is mainly regenerated by the decay of particulate organic phosphorus and by animals. In addition, their concentration in water and sediments is to a very large 
extent determined by biological activity. Microbe and animal activity can control phosphorus distribution and dynamics, because biological activity can change the redox potential of the sediments and hence, the chemical adsorption properties for phosphorus. Regarding nitrogen, in the anoxic experiments, all mineralised sediment particulate organic nitrogen and plant component nitrogen were found as an increase in the ammonia pool, that diffused upward to the overlying water, and it was more abundant than in aerobic situations. Although the concentration of dissolved inorganic nitrogen was higher in the anaerobic systems, the mineralisation rate of the nitrogen pool was higher in the oxic experiment. This is due to an uncoupling of nitrification and denitrification in the anaerobic systems, which results in high concentrations of ammonia $[6,11]$. In the oxic systems, the ammonification supplied the subsequent nitrification and denitrification, and hence, the mineralised nitrogen was transformed to $\mathrm{N}_{2}$ and lost. This pathway is considered as an important way to export nitrogen, when denitrification rates in salt marshes exceed nitrogen fixation [22]. In this study, the highest nitrification processes occurred when both macrofauna and meiofauna were also present, probably as a result of a better oxygen supply due to bioturbation, better carbon source or higher ammonia concentration. Since, bacterial growth takes place on DOC from the surface water or the sediment porewater [21], in aerobic sediments, most of the ammonium is released near the sediment surface, resulting from the decay and deposition of organic matter in the upper part of the sediment. In this experiment, benthic macrofauna were more abundant near the sediment surface, and their excretions probably contributed to high ammonium concentrations in the upper layers of the sediment [21]. Moreover, nitrifying bacteria convert the ammonium into nitrate, and the feeding activity of the benthos (bioturbation) increases the transport of nitrate down into the deeper anoxic part of the sediment where the denitrification takes place $[8,21]$. These may be the reason why denitrification rates were much higher under aerobic conditions and in the presence of macrofauna. These results are probably due to the fact that nitrification was inhibited in the anoxic experiments, and that the only denitrification that took place was the nitrate respiration of the initial nitrate concentration present in the estuarine water. In the anoxic experiment, the negative denitrification could be interpreted as an ongoing nitrogen fixation but, as there are high concentrations of ammonium available that could easily be available as nitrogen source, this result should probably not be taken under consideration since it may result from inadequate methodology.

The present study suggests that macrofauna and meiofauna have an important role in the ecosystem nutrient flux and that fauna might function as a sink for excess nutrients, that otherwise would be exported to coastal waters.

\section{Acknowledgments}

This study was carried out in the scope of the WET-project, (Wetland Ecology and Technology), financed by the European scientific TMR programme, (TMR) (ERB 4061 PL 95-0832) and by JNICT (Portuguese National Institution for Scientific Research) by conceding a Ph.D. grant (BD/ 9290/ 96) in the scope of the Praxis XXI programme.

\section{REFERENCES}

[1] Alpkem, RFA - Metholology A303-S202, A303-S170, A303S020, Alpkem Corporation, Clackamas, Oregon, USA, 1990.

[2] Azeiteiro U.M.M., Marques J.C., Temporal and spatial structure in the suprabenthic community of a shallow estuary (western Portugal: Mondego river estuary), Acta Oecol. 20 (1999) 333-342.

[3] Barnes R.S.K., An experimental study of the pattern and significance of the climbing behaviour of Hydrobia ulvae, J. Mar. Biol. Assoc. UK 61 (1981) 285-299.

[4] Barnes R.S.K., Hughes R., An Introduction to Marine Ecology, 2nd ed., Blackwell Scientific Publications, Oxford, 1988, $351 \mathrm{p}$.

[5] Enriques E., Duarte C.M., Sand-Jensen K., Patterns in decomposition rates among photosynthetic organisms: the importance of detritus C:N:P content, Oecologia 94 (1993) 457-471.

[6] Flindt M.R., Salomonsen J., Søndergaard M., Tornblom E., Decomposition of Ulva lactuca and Zostera marina. I. Mass balance in aerobic and anaerobic experiments, in: Studies and modelling of Ulva lactuca L., Ph.D. thesis of J. Salomonsen, Royal School of Pharmacy, Denmark, 1997.

[7] Flindt M.R., Pardal M.A., Lillebø A.I., Martins I., Marques J.C., Nutrient cycling and plant dynamics in estuaries: A brief review, Acta Oecol. 20 (1999) 237-248.

[8] Franck G., Stora G., Bonin P., Influence of bioturbation on denitrification activity in Mediterranean coastal sediments: an in situ experimental approach, Mar. Ecol. Prog. Ser. 163 (1998) 99-107.

[9] Godshalk G.L., Wetzel R.G., Decomposition of aquatic angiosperms. III. Zostera marina L. and conceptual model of decomposition, Aquat. Bot. 5 (1978) 329-354.

[10] Hill B.H., Perrot Jr W.T., Microbial colonization, respiration, and breakdown of maple leaves along a stream-marsh continuum, Hydrobiologia 312 (1995) 11-16.

[11] Kamp-Nielsen L., Flindt M.R., On-line recording of porewater profiles from in situ dialysis, Verh. Int. Verein. Limnol. 25 (1993) 151-156.

[12] Kristensen E., Decomposition of macroalgae, vascular plants and sediment detritus in seawater: use of stepwise thermogravimetry, Biogeochimistry 26 (1994) 1-24. 
[13] Lillebø A.I., Estrutura populacional, dinâmica e produção de Hydrobia ulvae (Pennant) (Mollusca: Prosobranchia) ao longo de um gradiente de eutrofização no estuário do Mondego (Portugal), M.Sc. thesis, University of Coimbra, Portugal, 1996, $111 \mathrm{p}$.

[14] Marques J.C., Martins I., Teles-Ferreira C., Cruz C., Population dynamics, life history, and production of Cyathura carinata (Krøyer) (Isopoda: Anthuridae) in the Mondego estuary, Portugal, J. Crustac. Biol. 14 (1994) 258-272.

[15] Martins I., Oliveira J.M., Flindt M.R., Marques J.C., The effect of salinity on the growth rate of the macroalgae enteromorpha intestinalis (Chlorophyta) in the Mondego estuary (west Portugal), Acta Oecol. 20 (1999) 259-265.

[16] Morrisson P.G., Detrital processing in seagrass systems: A review of factors affecting decay rates, remineralization and detritivory, Aquat. Bot. 23 (1989) 263-288.
[17] Pardal M., Impacto da eutrofização nas comunidades bentónicas do Braço Sul do estuário do Mondego, Ph.D. thesis, University of Coimbra, Portugal, 1998.

[18] Peterson B.J., Stable isotopes as tracers of organic matter input and transfer in benthic food webs: A review, Acta Oecol. 20 (1999) 479-487.

[19] Pozo J., Colino R., Decomposition processes of Spartina maritima in a salt marsh of the Basque Country, Hydrobiologia 231 (1992) 165-175.

[20] Teal J.M., Energy flow in the salt marsh ecosystem of Georgia, Ecology 43 (1962) 614-624.

[21] Valiela I., Marine Ecological Processes, 2nd ed., SpringerVerlag, New York, 1995, pp. 385-461.

[22] Valiela I., Teal J.M., The nitrogen budget of a salt marsh ecosystem, Natura 280 (1979) 652-656.

[23] Zar J., Biostatistical Analysis, 3rd ed., Prentice-Hall International, Upper Saddle River NJ, 1996. 